\title{
Risk Factors of Maternal Death in Karanganyar, Central Java, Indonesia
}

\author{
Noferi Kusnadi, Supriyadi Hari Respati, Sri Sulistyowati \\ Department of Obstetrics and Gynecology, Dr. Moewardi Hospital/ \\ Faculty of Medicine, Universitas Sebelas Maret
}

\begin{abstract}
Background: The maternal mortality rate is an indicator of national health status. To reduce the Maternal Mortality Rate (MMR), especially in Karanganyar Regency, the risk factors that affect the maternal mortality must be known.

Subjects and Method: This was a case-control study conducted in Karanganyar, Central Java, from 2016 to 2017. A sample of 57 study subjects was selected by fixed disease sampling. The dependent variable was maternal mortality. The independent variables were pregnancy complications, labor complications, postpartum complications, maternal age, distance of pregnancy, parity, maternal nutritional status during pregnancy, number of antenatal care visits, delay in making decisions, late referrals, late handling of staff, maternal education, maternal work, and income family. Data collected using questionnaires were then analyzed using bivariate analysis and multivariate analysis.

Results: Maternal mortality was affected by pregnancy complications (OR $=6.98 ; 95 \% \mathrm{CI}=2.06$ to $23.71 ; \mathrm{p}=0.001)$, labor complication $(\mathrm{OR}=7.59 ; 95 \% \mathrm{CI}=2.19$ to $26.28 ; \mathrm{p}=0.001)$, delayed labor $(\mathrm{OR}=5.39 ; 95 \% \mathrm{CI}=1.17$ to $24.75 ; \mathrm{p}=0.021)$, and family income $(\mathrm{OR}=4.29 ; 95 \% \mathrm{CI}=1.28$ to 14.41 ; $\mathrm{p}=0.015)$.

Conclusion: Maternal mortality was affected by pregnancy complications, labor complication, delayed labor, and family income.
\end{abstract}

Keywords: risk factors, maternal mortality, Karanganyar Regency

\section{Correspondence:}

Noferi Kusnadi. Department of Obstetrics and Gynecology, Dr. Moewardi Hospital/ Faculty of Medicine, Universitas Sebelas Maret, Surakarta, Central Java. Mobile: 08112654789. Email: noferikusnadi.og@gmail.com

\section{BACKGROUND}

Maternal mortality is defined as the death of a woman during pregnancy or within 42 days of delivery, regardless of duration, location, any cause associated with or exacerbated by pregnancy or management, but not due to accident or incidental causes (WHO, 2011). The mortality rate is an indicator of health status in the National Health Insurance (JKN) until 2019 so management of maternal health and avoidance of maternal mortality is very important (RI Ministry of Health, 2015).

Maternal Mortality Rate is the scale used to determine the number of maternal deaths in a country. The results of the 2013 statistics, the worldwide maternal mortality rate of 289,000 people (WHO, 2014). It is estimated that in 2015, around 303,000 women died during pregnancy and after childbirth (Alkema et al., 2016). The ratio of maternal mortality in developing countries in 2015 was 239 per 100,000 live births and in developed countries that is 12 per 100,00o live births (WHO, 2016).

Data from the Health Profile of Central Java Province in 2015, maternal mortality rates were $\mathbf{1 1 1 . 1 6}$ per 100,00o live births, a decrease compared to the previous year at 126.55 per 100,000 live births. From this 
Journal of Maternal and Child Health (2019), 4(6): 499-506

https://doi.org/10.26911/thejmch.2019.04.06.10

profile, it was also found that in most of the Subosukowonosraten areas (Surakarta, Boyolali, Karanganyar, Sukoharjo, Wonogiri, Sragen and Klaten). In 2015, there were 107 cases of maternal deaths, an increase from the previous year of 94 cases (Central Java Provincial Health Office, 2015; Health Office of Central Java Province, 2016). Maternal mortality in Karanganyar Regency was the third highest after Boyolali and Sukoharjo, which amounted to 16 cases in 2015, only slightly down from the previous year which was 17 cases (Central Java Provincial Health Office, 2015; Central Java Provincial Health Office, 2016). In 2016-2017, there were 19 cases of maternal deaths in Karanganyar Regency. The high maternal mortality rate in Karanganyar Regency is caused by obstetric complications during pregnancy, childbirth, indirect causes of death such as previous pregnancy history, antenatal care, delay and socio-demographic (Central Java Provincial Health Office, 2016).

Most cases of maternal deaths are caused by factors related to pregnancy complications, complications of childbirth and postpartum complications, reproductive status factors including maternal age, pregnancy distance and parity, health status factors, nutritional status, health service use factors, number of ANC visits (Central Java Provincial Health Office, 2016). The purpose of this study was to determine the risk factors that affect maternal mortality in Karanganyar Regency.

\footnotetext{
SUBJECTS AND METHOD

\section{Study Design}

This study was an analytical observational study with a case-control study design. The data collection was carried out in April-July 2018 in Karanganyar Regency. The retrieval of maternal mortality data was taken at the Karanganyar District Health Office and
}

control data was taken at the public health center in which there were maternal deaths in 2016-2017.

\section{Population and Samples}

The source population was all mothers who had pregnancy, childbirth, and childbirth in Karanganyar Regency. A sample of 57 study subjects was selected by fixed disease sampling.

\section{Study Variables}

The dependent variable was maternal mortality. The independent variables were pregnancy complication, labor complication, postpartum complication, maternal age, birth spacing, parity, maternal nutritional status during pregnancy, number of ANC visits, delay in making decision, maternal education, maternal work, and family income.

\section{Operational Definition of Variables}

Maternal mortality was a death that occurs to the mother during pregnancy and or within 42 days after the end of pregnancy, caused by complications of pregnancy, childbirth, and postpartum or its handling and illnesses suffered before or during pregnancy, aggravated by pregnancy and not accidental death.

Pregnancy complication was complications that occur during the last pregnancy, which can include bleeding, preeclampsia/eclampsia, infection. Labor complication was complications that occur during labor in the form of bleeding, prolonged labor, infection, preeclampsia/eclampsia, shock, placental abnormalities, abnormalities that occur before or during labor.

Postpartum complication was complications that occur within 42 days after the end of pregnancy, in the form of puerperal infection, preeclampsia/eclampsia, postpartum bleeding. Mother's age is the age of the mother during the last pregnancy. Parity was the number of births a mother has ever experienced. 
Pregnancy distance is the time span between the previous pregnancy and the last pregnancy. Nutritional status is the nutritional condition of the mother during pregnancy as measured by the Body Index (BMI). The number of antenatal care visits is the number of antenatal care by medical experts both midwives / obstetricians to the mother during pregnancy.

Delay is a delay in the transfer of a mother during a complication during pregnancy, childbirth, to a more complete health service facility, with more skilled birth attendant.

A referral place is a hospital and because it refers to medical complications during pregnancy, childbirth, or childbirth.

Maternal education is the last formal education that a mother has ever lived until the last labor. Occupation is an activity carried out in addition to being a housewife in the period of pregnancy until delivery. Family income is the amount of income (Rupiah) each month to meet the needs of family.

\section{Data Analysis}

Bivariate analysis was carried out using Chi-Square test. Multivariate analysis was carried out using multiple logistic regression analysis at a significance level of 95\%.

\section{Research Ethics}

The study was equipped with informed concern, anonymity, confidentially. Research ethics was obtained from the Research
Ethics Committee Dr. Moewardi Hospital, Faculty of Medicine, Universitas Sebelas Maret, Surakarta, Central Java, with number: 648/VIII/HREC / 2018.

\section{RESULTS \\ 1. Bivariate Analysis \\ The results of bivariate analysis showed} that complication during pregnancy $(\mathrm{OR}=$ 6.98; $95 \% \mathrm{CI}=2.06$ to $23.71 ; \mathrm{p}=0.001)$, labor complication $(\mathrm{OR}=7.59$; 95\% CI: 2.19 to 26.28 ; $\mathrm{p}=0.001$ ) were associated with maternal mortality.

Maternal age 20-35 years old (OR= $0.51 ; 95 \% \mathrm{CI}=0.14$ to $1.86 ; \mathrm{p}=0.306)$, birth space $<2$ years $(\mathrm{OR}=0.49 ; 95 \% \mathrm{CI}=0.15$ to 1.64; $\mathrm{p}=0.244)$, and parity $<4$ times $(\mathrm{OR}=$ $0.25 ; 95 \% \mathrm{CI}=0.023$ to $2.16 ; \mathrm{p}=0.178$ ) decreased the risk of maternal mortality.

Poor nutritional status increased the risk of maternal mortality $(\mathrm{OR}=1.37$; $95 \%$ CI: 0.456 to $4.14 ; p=0.574)$ but it was statistically non-significant.

The results of the bivariate analysis statistically had no significant effect between the delay in making decisions and maternal mortality $(\mathrm{OR}=2.73 ; 95 \% \mathrm{CI}=$ 0.82 to $9.05 ; \mathrm{p}=0.095)$. The delay in referring statistically had a significant effect between late referring to maternal death $(\mathrm{OR}=5.39 ; 95 \% \mathrm{CI}=1.17-24.75 ; \mathrm{p}=0.021)$.

ANC visit $\geq 4$ times reduced the risk of maternal mortality $(\mathrm{OR}=0.41 ; 95 \% \mathrm{CI}=$ 0.10 to $1.66 ; p=0.202$ ).

Table 1. Factors related to obstetric complications in Karanganyar Regency

\begin{tabular}{|c|c|c|c|c|c|c|c|}
\hline \multirow{2}{*}{ Obstetric Complications } & \multicolumn{2}{|c|}{ Case } & \multicolumn{2}{|c|}{ Control } & \multirow{2}{*}{$\mathbf{O R}$} & \multirow{2}{*}{$95 \% \mathrm{CI}$} & \multirow{2}{*}{$\mathbf{P}$} \\
\hline & $\mathbf{N}$ & $\%$ & $\mathbf{N}$ & $\%$ & & & \\
\hline \multicolumn{8}{|l|}{$\begin{array}{l}\text { Pregnancy Complication } \\
\end{array}$} \\
\hline Yes & 13 & 68.4 & 9 & 23.7 & 6.98 & \multirow{2}{*}{$2.06-23.71$} & \multirow[t]{2}{*}{0.001} \\
\hline No & 6 & 31.6 & 29 & 76.3 & & & \\
\hline \multicolumn{8}{|l|}{ Labor complication } \\
\hline Yes & 12 & 63.2 & 7 & 18.4 & 7.59 & \multirow{2}{*}{$2.19-26.28$} & \multirow[t]{2}{*}{0.001} \\
\hline No & 7 & 36.8 & 31 & 81.6 & & & \\
\hline \multicolumn{8}{|l|}{ Complications of puerperal } \\
\hline Yes & 6 & 31.6 & - & - & - & - & $<0.001$ \\
\hline No & 13 & 68.4 & 38 & 100.0 & & & \\
\hline
\end{tabular}


Journal of Maternal and Child Health (2019), 4(6): 499-506

https://doi.org/10.26911/thejmch.2019.04.06.10

Table 2. High Risk Pregnancy Factors

\begin{tabular}{|c|c|c|c|c|c|c|c|}
\hline \multirow{2}{*}{ High Risk } & \multicolumn{2}{|c|}{$\begin{array}{c}\text { Case } \\
(n=19)\end{array}$} & \multicolumn{2}{|c|}{$\begin{array}{c}\text { Control } \\
(n=38)\end{array}$} & \multirow{2}{*}{$\mathbf{O R}$} & \multirow{2}{*}{$95 \%$ CI } & \multirow{2}{*}{$\mathbf{p}$} \\
\hline & $\mathbf{N}$ & $\%$ & $\mathbf{N}$ & $\%$ & & & \\
\hline \multicolumn{8}{|l|}{ Maternal Age } \\
\hline$<19$ years or $>35$ years & 4 & 21.1 & 13 & 34.2 & 0.51 & $0.14-1.86$ & 0.306 \\
\hline $19-35$ years & 15 & 78.9 & 25 & 65.8 & & & \\
\hline \multicolumn{8}{|l|}{ Parity } \\
\hline$<4$ times & 8 & 42.1 & 6 & 10.5 & 6.18 & $1.78-21.42$ & 0.178 \\
\hline$\geq 4$ times & 18 & 94.7 & 31 & 81.6 & & & \\
\hline \multicolumn{8}{|l|}{ Birth space } \\
\hline$<2$ years & 5 & 26.3 & 16 & 42.1 & 0.49 & $0.15^{-1.64}$ & 0.244 \\
\hline$\geq 2$ years & 14 & 73.7 & 22 & $57 \cdot 9$ & & & \\
\hline \multicolumn{8}{|l|}{ Nutritional Status } \\
\hline Good (BMI: 18.5-25.0) & 9 & $47 \cdot 3$ & 21 & $55 \cdot 3$ & 1.37 & $0.46-4.14$ & 0.574 \\
\hline Poor (BMI: <18.5 or >25.0) & 10 & 52.6 & 17 & 44.7 & & & \\
\hline
\end{tabular}

Table 3. Factors related to health services in Karanganyar Regency

\begin{tabular}{|c|c|c|c|c|c|c|c|}
\hline \multirow[t]{2}{*}{ Delay } & \multicolumn{2}{|c|}{$\begin{array}{c}\text { Case } \\
(n=19)\end{array}$} & \multicolumn{2}{|c|}{$\begin{array}{c}\text { Control } \\
(n=38)\end{array}$} & \multirow[t]{2}{*}{$\mathbf{O R}$} & \multirow[t]{2}{*}{$95 \% \mathrm{CI}$} & \multirow[t]{2}{*}{$\mathbf{P}$} \\
\hline & $\mathbf{N}$ & $\%$ & $\mathbf{N}$ & $\%$ & & & \\
\hline \multicolumn{8}{|l|}{ Delay in making a decision } \\
\hline Late ( $>30$ minutes) & 8 & 42.1 & 8 & 21.1 & 2.73 & $0.82-9.05$ & 0.095 \\
\hline Normal (<30 minutes) & 11 & 57.9 & 30 & 78.9 & & & \\
\hline \multicolumn{8}{|l|}{ Late referral } \\
\hline Late ( $>2$ hours) & 6 & 31.6 & 3 & 7.9 & $5 \cdot 39$ & $1.17-24.75$ & 0.021 \\
\hline Normal (<2 hours) & 13 & 68.4 & 35 & 92.1 & & & \\
\hline \multicolumn{8}{|l|}{ Delay in handling officers } \\
\hline Late ( $>30$ minutes) & 3 & 15.8 & - & - & - & - & 0.012 \\
\hline Normal (<30 minutes) & 16 & 84.2 & 38 & 100.0 & & & \\
\hline \multicolumn{8}{|l|}{ ANC } \\
\hline$<4$ times & 3 & 15.2 & 12 & 31.6 & 0.41 & $0.10-1.66$ & 0.202 \\
\hline$>4$ times & 16 & 84.2 & 26 & 68.4 & & & \\
\hline
\end{tabular}

Table 4. Socio-economic factors in Karanganyar Regency

\begin{tabular}{|c|c|c|c|c|c|c|c|}
\hline \multirow{2}{*}{ Socio-economic } & \multicolumn{2}{|c|}{$\begin{array}{c}\text { Case } \\
(n=19)\end{array}$} & \multicolumn{2}{|c|}{$\begin{array}{l}\text { Control } \\
(n=57)\end{array}$} & \multirow{2}{*}{$\mathbf{O R}$} & \multirow{2}{*}{$95 \%$ CI } & \multirow{2}{*}{$\mathbf{p}$} \\
\hline & $\mathbf{N}$ & $\%$ & $\mathbf{N}$ & $\%$ & & & \\
\hline \multicolumn{8}{|l|}{ Education } \\
\hline Low & 12 & 63.2 & 30 & 78.9 & 0.46 & $0.14-1.54$ & 0.202 \\
\hline High & 7 & 36.8 & 8 & 21.1 & & & \\
\hline \multicolumn{8}{|l|}{ Occupation } \\
\hline Working & 7 & 36.8 & 11 & 28.9 & 1.43 & $0.45-4.60$ & 0.546 \\
\hline Not working & 12 & 63.2 & 27 & 71.1 & & & \\
\hline \multicolumn{8}{|l|}{ Income } \\
\hline Low < Karanganyar Minimum wage & 14 & 73.7 & 15 & 39.5 & 4.29 & $1.28-14.41$ & 0.015 \\
\hline High $\geq$ Karanganyar Minimum wage & 5 & 26.3 & 23 & 60.5 & & & \\
\hline
\end{tabular}


The results of bivariate analysis showed no significant effect between education and maternal mortality $(\mathrm{OR}=0.46$; 95\% CI: 0.14 - 1.54; $\mathrm{p}=0.202$ ). Occupation had no effect on maternal mortality (OR = $1.43 ; 95 \% \mathrm{CI}=0.45$ to $4.60 ; \mathrm{p}=0.546)$. Statistically, there was a significant influence between family income and maternal

Table 5. The final logistic regression model

\begin{tabular}{lccc}
\hline Variable & b & $\mathbf{9 5 \%}$ CI & p \\
\hline Pregnancy complication & 1.485 & $0.051-1.008$ & 0.051 \\
Labor complication & 1.617 & $0.043-0.925$ & 0.040 \\
Complications of postpartum & 21.169 & - & 0.999 \\
Late Referral & 1.901 & $0.022-1.017$ & 0.052 \\
N observation $=57$ & & & \\
-2 log likehood $=72.56$ & & & \\
Nagelkerke $\mathrm{R}^{2}=54.7 \%$ & & & \\
\hline
\end{tabular}

mortality $(\mathrm{OR}=4.29 ; 95 \% \mathrm{CI}: 1.28$ - 14.41; $\mathrm{p}=0.015)$.

\section{Multivariate Analysis}

Table 5 shows that labor complications increased the risk of maternal mortality $(\mathrm{b}=$ $1.62 ; 95 \% \mathrm{CI}=0.04$ to $0.93 ; \mathrm{p}=0.040$ ) and it was statistically significant.

\section{DISCUSSION \\ 1. The effects of pregnancy complica- tions on maternal death}

The results of this study showed that complication during pregnancy increased the risk of maternal death 6.98 times.

Hypertension in pregnancy, which is often encountered, namely preeclampsia and eclampsia, if not addressed immediately will result in the mother losing awareness that continues to occur in heart failure, kidney failure or brain hemorrhage which will result in maternal death (Shennan et al, 2017).

Given severe preeclampsia, the majority causes complications of pregnancy. Therefore, severe preeclampsia is associated with an increased risk of maternal mortality by $0.2 \%$ and increased maternal morbidity by $5 \%$, such as convulsions, pulmonary edema, acute renal or hepatic failure, diseminated liver bleeding, intravascular discomfort, coagulopathy, and stroke. This complication is usually seen in women who experience 32 weeks of preeclampsia and those with pre-existing medical conditions (Ghulmiyyah and Sibai, 2012). Astuti et al. (2017) stated that complication during pregnancy increased the risk of maternal death $75 \%$ among pregnant women with preeclampsia.

\section{The effect of labor complications on maternal death}

The results of bivariate analysis showed that labor complications were associated with maternal mortality.

The results of this study are consistent with research conducted by Astuti et al. (2017) that labor complications have a risk of 5.08 times maternal mortality. Muthoharoh et al. (2016) reported the risk level of complications with maternal mortality was 4.23 times. The Haeri and Dildy (2012) study examined that labor complications caused by postpartum hemorrhage were the main cause (99\%) of maternal mortality within 24-48 hours. Devi et al. (2015) in his study showed that postpartum hemorrhage caused maternal mortality by $53.19 \%$.

In this study, the complications of labor, especially postpartum haemorrhage, also included labor complications, contribute $25 \%$ to the occurrence of maternal mortality. This bleeding will cause the mother to lose a lot of blood, and will result in death in a short time (WHO, 2016). Mild 
preeclampsia can easily turn to severe preeclampsia and this condition will easily become eclampsia resulting in seizures. If this condition occurs in the labor process, it can cause the mother to lose consciousness and cause death (WHO, 2012).

\section{Effect of postpartum complications on maternal death}

The results of bivariate analysis showed that post partum complications were associated with maternal mortality.

Halder et al. (2015) showed that postpartum complications have a high risk of maternal mortality. The existence of complications during puerperium, especially the presence of infection can cause maternal death due to the spread of germs into the bloodstream (septicemia), which can cause abscesses in organs, such as the brain and kidneys, while postpartum bleeding can continue to occur, especially if the mother does not immediately get initial treatment to control bleeding (Halder et al, 2015).

\section{The effect of late referring on maternal death}

The results of this study showed that there was an influence between late referring on maternal mortality. The results of this study are in accordance with Aeni (2013) study that late referrals are at risk with the occurrence of maternal mortality.

The referral system, especially in midwifery services, must be carried out appropriately and must avoid three late, namely delays in decision making, delays in reaching the destination of referrals and delays in obtaining services at the referral place. The results showed that more than $75 \%$ of mothers who had complications had been referred to when complications occurred in both the case group and the control group, so that the referral system had been running, only in its implementation should it be seen whether there were three delays in the referral (Indonesian Ministry of Health, 2013).

The results of the study showed that most of them were not late in reaching the referral place, because in general, the problems in reaching the referral point were geographical problems, transportation availability, patient stabilization complications were not carried out or were ineffective, and monitoring patients as long as referrals were not done or not followed up (Indonesian Ministry of Health, 2013).

\section{The effect of late complication management on maternal death}

The results of this study showed that that late complication management was associated with maternal mortality. The results of this study are in accordance with the study of Kumar and Agrawal (2016) in his study of "Brought in Dead: An Avoidable Delay in Maternal Deaths" that the delay in handling officers became a factor causing maternal mortality by $56.25 \%$. The delay in handling the officers in this study was caused by there being no empty rooms and patients were able to wait.

\section{The effect of income on maternal death}

The results of this study showed that family income was associated with maternal mortality. This means that patients who have family income under the minimum wage have a 4.29 times risk of maternal mortality. The results of this study are consistent with the study of Muthoharoh et al. (2016) and Aeni (2013) that family income that is less than MSE is a risk factor with the incidence of maternal deaths.

\section{ACKNOWLEDGEMENT}

The author would like to thank the officers of the public health centers, cadres and mothers who have participated in this study and also the Karanganyar Bappeda Office 
and Karanganyar Health Office who gave permission in this study.

\section{FUNDING AND SPONSORSHIP}

This study is self-funded.

\section{CONFLICT OF INTEREST}

The author states that this study was carried out without any commercial or financial relationship that can be interpreted as a potential conflict of interest.

$\frac{\text { REFERENCE }}{\text { Aeni N (2013). Faktor risiko kematian ibu }}$
(Risk factors for maternal death). Jurnal Kesehatan Masyarakat Nasional. 7(10):453-59.

Alkema L, Doris C, Daniel H, Sanqian Z, Ann-Beth M, Alison G, Doris MF, Ties B, Marleen T, Colin M, Lale S (2016). Global, regional, and national levels and trends in maternal mortality between 1990 and 2015, with scenario-based projections to 2030: a systematic analysis by the UN Maternal Mortality Estimation Inter-Agency Group. The Lancet. 387 (10017): 462-474.

Astuti SK, Aziz MA, Arya IFD (2017). Maternal mortality risk factors in Dr. Hasan Sadikin General Hospital, Bandung in 2009-2013. International Journal of Integrated Health Sciences. 5(2): 52-56.

Devi KP, Singh LR, Sing B, Singh MR, Sing NN (2015) . Postpartum Hemorrhage and Maternal Deaths in North East India. Open Journal of Obstetrics and Gynecology. 5: 635-638.

Central Java Provincial Health Office (2015). Profil Kesehatan Provinsi Jawa Tengah Tahun 2014 (2014 Central Java Health Profile). Semarang.
Central Java Provincial Health Office (2016). Profil Kesehatan Provinsi Jawa Tengah Tahun 2015 (Health Profile of Central Java Province in 2015). Semarang.

Ghulmiyyah L, Sibai B (2012). Maternal mortality from preeclampsia/eclampsia, Seminars in Perinatology; 36(1): 56-59.

Haeri S, Dildy GA (2012). Maternal Mortality From Hemorrhage. Seminar Perinatology; 36: 48-55.

Halder A, Vijayselvi R, Jose R (2015). Changing perspectives of infectious causes of maternal mortality. Journal Turkish-German of Gynecological Association. 16(4):208-213.

Ministry of Health of the Republic of Indonesia (2015). Profil Kesehatan Indonesia Tahun 2014 (Indonesia Health Profile 2014). Jakarta: Kementerian Kesehatan RI.

Ministry of Health of the Republic of Indonesia (2013). Riset Kesehatan Dasar (Basic Health Research). Jakarta: Badan Penelitian dan pengembangan Kesehatan Kementrian Kesehatan RI.

Kumar N (2016). Postpartum Hemorrhage: A major killer of woman: Review of current scenario. Obstetrics \& Gynecology International Journal; 4(4): $1-7$.

Kumar A, Agrawal N (2016). Brought in dead: An avoidable delay in maternal death. Jurnal Obstetrics \& Gynecology India; 66(1): 6-60.

Muthoharoh NA, Purnomo I, Nurlatif V (2016). Faktor-faktor yang berhubungan dengan kematian maternal di Kabupaten Batang (Factors related to maternal mortality in Batang Regency). Jurnal Pena Medika. 6(1):1-18.

Shennan AH, Green M, Chappell LC (2017). Maternal deaths in the UK: pre- 
Journal of Maternal and Child Health (2019), 4(6): 499-506

https://doi.org/10.26911/thejmch.2019.04.06.10

eclampsia deaths are avoidable. The Lancet. 389(10069): 582-584.

WHO (2016). Maternal mortality, fact sheet. Retrieved from http://www.who.int/mediacentre/factsheets/fs$348 / \mathrm{en} /$.

WHO (2014). Trends in Maternal Mortality: 1990 to 2013. Retrieved from http://apps.who.int/iris/bitstream/- 10665/112682/2/9789241507226_en g.pdf

WHO (2011). Unsafe abortion: Global and regional estimates of the incidence of unsafe abortion and associated mortality in 2008. Sixth Edition. WHO. 